\title{
Price Stabilisation and Microeconomic Reforms in Brazil
}

\section{Flavio Menezes}

\begin{abstract}
$\mathrm{C}$ hanges in the structure of the Brazilian economy have been centred on three basic pillars: price stabilisation, fiscal reform and microeconomic reforms. The main thesis of this paper is that the reforms made the economy more resilient to external shocks, but that more changes are required, especially with respect to Federal-State relations and competition policy. Although the reforms started in the early 1990s with President Fernando Collor, who was impeached on charges of corruption halfway through his term, they only took shape after the stabilisation of prices following the introduction of the real in July 1994. With price stabilisation, it became imperative to address what was recognised as the most important cause of the high inflation, namely, the disorganisation of the public sector with the fiscal imbalances being financed by printing money. Addressing the fiscal imbalances, however, required major reforms to reduce the control of the state over economic activity. These reforms range from privatisation and deregulation to the liberalisation of capital markets and international trade; and from competition policy to financial markets reform. So great was the extent and scope of the reforms that constitutional amendment was required. Parliament amended the 1988 Constitution to abolish the existing distinction between Brazilian firms owned by Brazilians and those owned by foreigners and to allow foreign participation in telecommunications, transport, gas, oil and mineral exploration and production, and electricity distribution and generation.
\end{abstract}

\section{An Overview of the Economy}

The Federative Republic of Brazil is located in South America. It is a federation of twenty-six states and the federal district of Brasilia. The population is diverse in origin, an amalgam of indigenous, African, and European peoples. Table 1 summarises some of Brazil's main geographical features. The largest South American country (area: 8.5 million square $\mathrm{km}$ ), the fifth largest and the sixth most populous country in the world (1996 population: 157 million), Brazil occupies almost half the continent. It has a diverse topography and climate, ranging from tropical in the rain forests of the great Amazon basin in the north to temperate in the highlands of the heavily populated east and south, which make up two thirds of the country's land and contain its most important economic centres.

Flavio Menezes is Lecturer in Economics in the Department of Economics, Faculties, at The Australian National University. 
Brazil is the world's seventh or eighth largest economy with a GDP in 1996 of US $\$ 804$ billion (evaluated at the average annual exchange rate). This is more than twice Australia's. Although it has become increasingly industrialised since the 1960 s, the agricultural sector still plays a very important role.

\section{Table 1: Some Vital Indicators}

\begin{tabular}{|l|l|}
\hline Borders & $\begin{array}{l}\text { Venezuela, Guyana, Suriname, and French Guiana } \\
\text { (North); Colombia, Peru, and Bolivia (West), Paraguay, } \\
\text { Argentina, and Uruguay (Southwest); and the Atlantic } \\
\text { Ocean (East). }\end{array}$ \\
\hline Official Language & Portuguese \\
\hline Predominant Religion & Roman Catholicism \\
\hline Principal Cities & $\begin{array}{l}\text { São Paulo, Rio de Janeiro, Recife, Belo Horizonte, } \\
\text { Salvador and Porto Alegre. }\end{array}$ \\
\hline Most Important States & $\begin{array}{l}\text { São Paulo, Rio de Janeiro, Minas Gerais, Rio Grande do } \\
\text { Sul and Pernambuco. }\end{array}$ \\
\hline Major Crops & $\begin{array}{l}\text { Coffee, cocoa, cotton, sugar cane, oranges, corn, tobacco, } \\
\text { bananas, and soybeans }\end{array}$ \\
\hline Major Industrial Products & $\begin{array}{l}\text { Motor vehicles, steel, cotton textiles, paper, fertilizer, } \\
\text { cement, and machinery. }\end{array}$ \\
\hline Mineral Reserves & $\begin{array}{l}\text { Iron, quartz, coal, manganese, chromium, industrial } \\
\text { diamonds, uranium, petroleum and platinum. }\end{array}$ \\
\hline
\end{tabular}

Source: Instituto Brasileiro de Geografia e Estatística (IBGE)(www.ibge.gov.br).

Table 2 provides a picture of the evolution of the Brazilian economy. While the average annual real growth rate of GDP in the twentieth century was five per cent, the growth rate in the industrial sector was nearly twice that of the agricultural sector. This reflects the process of industrialisation of the economy, a dominant theme in the development of the Brazilian economy this century.

\section{Table 2: Percentage Average Annual Real Growth Rates}

\begin{tabular}{|r|c|c|c|}
\hline Period & GDP & Agricultural Sector & Industrial Sector \\
\hline $1970 / 1980$ & 8.6 & 4.7 & 9.0 \\
\hline $1980 / 1990$ & 1.6 & 2.4 & -0.2 \\
\hline $1990 / 1996$ & 2.8 & 4.1 & 2.0 \\
\hline $1900 / 1996$ & 5.0 & 3.6 & 6.0 \\
\hline
\end{tabular}

Source: Bonelli and Gonçalves (1998).

Table 2 also reveals the impact that the 1982 world financial crisis had on the Brazilian economy. The small but positive average annual GDP growth rate in that decade was a result solely of an expansion of the agricultural sector while the value 
of the output produced by the industrial sector declined an average of 0.2 per cent a year. The industrialisation process meant that the contribution of industry to GDP increased from 10 per cent of GDP in 1900 to 25 per cent in 1990 . At the same time, the contribution of agriculture to GDP decreased from 38 per cent of GDP to 10 per cent.

These aggregate data on the growth of the industrial sector fail to identify the changes in industry composition. Table 3 , below, classifies production into three groups: modern intermediate goods (including non-metallic minerals, metals, chemicals, plastics, paper and rubber), capital goods and durable consumption goods (including mechanical goods, electrical and transport materials), and traditional (including everything else such as non-durable goods). One of the main reasons for this shift from the traditional sector to the modern intermediate goods sector is the policy of trade liberalisation of the early 1990 s, resulting in the abolition of the import substitution policies from the 1960s and 1970 s.

\section{Table 3: Percentage of Total Production Value (Current Prices)}

\begin{tabular}{|l|c|c|c|l|}
\hline & 1970 & 1980 & $1990 / 1992 \mathrm{a}$ & $1993 / 1996 \mathrm{a}$ \\
\hline Traditional & 48.09 & 35.15 & 40.60 & 38.99 \\
\hline $\begin{array}{l}\text { Modern } \\
\text { intermediate } \\
\text { goods }\end{array}$ & 33.32 & 43.96 & 40.95 & 40.24 \\
\hline $\begin{array}{l}\text { Capital and } \\
\text { durable goods }\end{array}$ & 18.61 & 20.89 & 18.45 & 20.77 \\
\hline
\end{tabular}

a. Annual averages - constant 1985 prices.

Sources: Bonelli and Gonçalves (1998), Bonelli (1996) and UNIDO (1997).

Table 4 provides some insights into the changes in the Brazilian economy since the introduction of the real in July 1994. In addition to a sharp decline in the inflation rate following the introduction of the new currency, the economic growth rate averaged 4.25 per cent over the $1994 / 1997$ period, while the unemployment rate averaged five per cent in the same period. Monetary policy was kept tight for the first year of the real, resulting in an increase of the real interest rate to 33.4 per cent per annum. The Asian crisis and the subsequent speculative attack on the real saw the introduction of new fiscal austerity measures including tax increases and expense reductions (see below), and the tightening of monetary policy. As a result, the interest rate increased to 27.6 per cent in 1998, the unemployment rate increased to 7.5 per cent and the economy slowed to a halt with inflation being the lowest recorded in the last five decades.

Table 4 also provides an overview of the evolution of the twin deficits - the fiscal and current account deficits - since the introduction of the real. A high rate of inflation meant that fiscal deficits were easily financed by seigniorage. As a result, the government was able to finance a 5.3 per cent primary deficit (net of 
interest) and a nominal deficit of 45.5 per cent of GDP in 1994. (This is a standard example of how inflation distorts individual decisions; the nominal interest rate of 1,099 per cent a year distorted the relationship between the nominal deficit and GDP).

After the reduction in inflation, there was a primary surplus in 1995 with a negligible deficit in 1995. However, the nominal deficit has continued to increase as a result of high interest rates and, consequently, the fiscal deficit as a fraction of GDP increased to 38.6 per cent in 1998 . Despite the elections of 1998 , the primary deficit was kept at 0.6 per cent of GDP for 1998. The evolution of the current account deficit reflects both the appreciation of the real and the slowdown in the world economy following the Asian crisis.

\section{Table 4: Recent Economic Indicators}

\begin{tabular}{|c|c|c|c|l|c|c|c|c|}
\hline Year & $\begin{array}{l}\text { GDP } \\
\text { Real } \\
\text { Growth } \\
\text { Rate }\end{array}$ & $\begin{array}{l}\text { Inflation } \\
\text { IGP-DI }^{\mathrm{a}}\end{array}$ & $\begin{array}{l}\text { Unemp- } \\
\text { loyment } \\
\text { Rate }^{\mathrm{b}}\end{array}$ & $\begin{array}{l}\text { Real } \\
\text { Interest } \\
\text { Rate }\end{array}$ & $\begin{array}{l}\text { Fiscal } \\
\text { Debt }^{\mathrm{d}}\end{array}$ & $\begin{array}{l}\text { Primary } \\
\text { Deficit }^{\mathrm{e}}\end{array}$ & $\begin{array}{l}\text { Nominal } \\
\text { Deficit }^{\mathrm{f}}\end{array}$ & $\begin{array}{l}\text { Current } \\
\text { Account }\end{array}$ \\
\hline 1994 & 5.9 & $1,093.8$ & 5.1 & 5.0 & 17.7 & -5.3 & 45.5 & 0.3 \\
\hline 1995 & 4.2 & 14.8 & 4.6 & 33.4 & 16.8 & -0.4 & 7.2 & 2.5 \\
\hline 1996 & 2.8 & 9.3 & 4.7 & 16.5 & 22.6 & 0.1 & 5.9 & 3.1 \\
\hline 1997 & 3.7 & 7.5 & 5.7 & 16.1 & 29.5 & 1.0 & 6.1 & 4.2 \\
\hline $1998^{\mathrm{c}}$ & 0.2 & 0.7 & 7.5 & 27.6 & 38.6 & 0.6 & 8.0 & 4.4 \\
\hline
\end{tabular}

Notes:

There is a myriad of inflation measures in Brazil. The Getulio Vargas Foundation, an independent organisation, calculates the IGP-DI.

Annual average.

Preliminary estimates.

As a percentage of GDP.

Fiscal deficit net of interest payments as a percentage of GDP.

Fiscal deficit gross of interest payments as a percentage of GDP.

Sources: Conjuntura Econômica and IBGE.

This picture hides significant inequalities in the way the product is shared. Table 5 reports the fraction of total income received by those in the top 20 per cent of the income distribution scale and by those in the bottom 50 per cent of the income distribution scale. Income inequality has increased in the last decades. According to research by the Bureau of Statistics (IBGE), the top ten per cent received 49.8 per cent of the total national income in 1993, whereas the bottom ten per cent received only 0.7 per cent of the total national income. Price stabilisation is likely to improve income distribution because mostly the poor, who could not afford interest-bearing bank accounts, paid the inflationary tax. Moreover, the minimum wage did increase in real terms by more than 70 per cent in the first two 
years of the stabilisation plan and unemployment was reduced. However, price stabilisation is only a necessary condition for reducing income inequalities of this magnitude. Some of the policies aimed at reducing the production side of the public sector, letting the government get on with the task of addressing social issues and, simultaneously, allowing resources to be allocated more efficiently are addressed later.

\section{Table 5: Social Inequality Indicators}

\begin{tabular}{|c|c|c|c|}
\hline Period & $\begin{array}{c}\text { Annual average rate } \\
\text { of real growth of per } \\
\text { capita income }\end{array}$ & $\begin{array}{c}\text { Fraction of total } \\
\text { income hold by the } \\
\text { lower 50 per cent (end } \\
\text { of period) }\end{array}$ & $\begin{array}{c}\text { Fraction of total } \\
\text { income hold by the } \\
\text { top 20 per cent (end } \\
\text { of period) }\end{array}$ \\
\hline $1960-1970$ & 2.2 & 15 & 62 \\
\hline $1970-1980$ & 7.0 & 14 & 63 \\
\hline $1980-1990$ & -0.4 & 12 & 65 \\
\hline $1990-1995$ & 1.2 & 12 & 63 \\
\hline
\end{tabular}

Source: IBGE.

\section{Price Stabilisation}

The Economic Stabilisation Program consisted of three stages. After several heterodox experiments with price controls and freezing of financial assets, the cause of the high inflation was finally identified. Disorganisation within the public sector was imposing inflationary pressure on the economy as fiscal imbalances were financed by printing money.

Thus, the stabilisation program started in June 1993, under the supervision of the then Finance Minister Cardoso (now President). The Immediate Action Program (PAI) established a number of actions to reduce government expenditures for the 1993 fiscal year and to increase government revenue. PAI also addressed the chaotic situation of state and city fiscal debts and introduced controls on stateowned banks that were being used to finance states' deficits. Finally, PAI established as a priority the reorganisation of federally-controlled banks and an increase in the scope of the existing privatisation program.

The second stage started in December 1993 with establishment of the $U R V$ (Real Unit of Value). Prices, salaries and pensions were converted to $U R V$ that was related to the existing currency, the cruzeiro real, by means of a conversion table. The introduction of the URV addressed the need to break the inflationary memory built into existing contracts. Most contracts were linked to past inflation by means of formal indexation.

The third stage of the stabilisation program saw the introduction of the new currency, the real, in July 1994. From this date onwards all new contracts were nominated in reals and existing ones had to be converted to the new currency by using the conversion table. Overall, this was a unique experiment in price 
stabilisation perhaps with some elements of the 1923 Rentenmark reform in Germany.

With the real came very strict monetary rules that fixed the parity between the US dollar and the real at one-to-one. Moreover, the exchange rate anchor established full conversion of a real to a dollar and substantially increased Central Bank independence. Later full conversion at the one-to-one rate was replaced by a system of flexible bands with limited intervention. (For example, the band was set at US\$ 0.97-1.06 in September 1996. In January 1999 the band was set at US\$1.181.22).

As seen previously, the stabilisation program was successful in reducing the inflation rate from more than 1,000 per cent in 1994 to less than one per cent in 1998. Moreover, one of the great advantages of price stabilisation was to expose the true state of disorganisation within the public sector. As the ultimate objective of the stabilisation program was to lay the foundations for sustained economic growth in order to reduce the existing social imbalances, its accomplishment would depend on the scope and degree of success of microeconomic reform. These reforms are discussed in the next sections.

\section{The fiscal reform}

The starting point of our discussion is again the Immediate Action Program (PAI). Several measures were proposed to address the fiscal disequilibrium such as a reduction in government spending and an increase in taxes and in the government ability to fight fiscal evasion - a tax on bank transactions was introduced. Under PAI, states and cities that saw debts with the federal government renegotiated with the inclusion of limits to the ratio of the wage bill to revenues and severe restrictions on their ability to increase their debts. PAI also established as priorities the privatisation of state banks, the reorganisation of federal banks, and an expansion of the existing privatisation program.

As previously observed, this fiscal effort was partially successful in reducing the primary fiscal deficit and its share in the GDP for the first two years of the stabilisation program. The improvement in the fiscal imbalance was due mainly to the efforts by the federal government as the states and government-owned companies continued to generate primary deficits. Despite all the measures listed in the above paragraph and despite the announcement of a new set of fiscal austerity measures - involving another increase in taxes and further costs of government expenditures - at the end of 1997 (just after the onset of the Asian crisis), the fiscal deficit increased again in 1997 and 1998.

There are some plausible causes for such increase in the fiscal deficit. First, inflation has decreased beyond the government's most optimistic forecast. (The forecast for the 1998 inflation was six per cent). That meant that tax revenues increased by less than predicted. The reduction in economic growth also contributed to the reduction in tax revenues. The official forecast was that the economy would grow four per cent in 1998. Finally, many state governors used the 
additional resources from the state privatisation program to finance further spending.

After the Russian default and the new speculative attack on the real, a set of even more austere fiscal measures was introduced in October 1998. The objective was to generate a primary surplus of 2.6 per cent of GDP in 1999 , which would increase to a surplus of three per cent of GDP in 2001 (the 1999 primary surplus target has since been increased to 3.0 per cent of GDP. The increase comes from further cuts at the federal government level and an increase in the social security contributions from military personnel). The generation of a primary surplus of this magnitude requires the cooperation of cities and states and government-owned companies that are expected to generate primary surpluses of about 0.4 per cent of GDP per year.

This additional fiscal effort concentrated on further expenditure cuts, new increases in the tax over bank transactions and over firms' profits and an overhaul of a very generous social security system. These measures have already been approved by parliament. Legislation was also introduced to reform the inefficient tax system by replacing a myriad of taxes with a GST-type tax. In addition, the government also introduced legislation to parliament to liberalise the labour market and a law of fiscal responsibility establishing basic public administration principles such as maximum debt levels, and ratios between revenue and various expenditures. This proposal also characterises fiscal irresponsibility as a crime!

\section{The Microeconomic Reforms}

Perhaps one can identify the beginning of the reforms that would transform the Brazilian economy in the last five years as the trade liberalisation that started in early 1990s. The stabilisation program that followed was successful in controlling inflation and helped the start of a series of reforms to deal with a myriad of issues, from competition policy to the reorganisation of the financial system. This section describes some of these reforms.

\section{Trade liberalisation}

The foreign debt crisis of the early 1980 s symbolised the end of the importsubstitution process that allowed the Brazilian economy to record growth rates considerably higher than the rest of the world for more than three decades after the Second World War. The immediate response to the foreign debt crisis was further to increase the degree of protection (both through tariffs and non-tariff barriers) postponing the end of the import-substitution era to the end of the $1980 \mathrm{~s}$.

The trade liberalisation process can be divided into two stages. The first stage occurred in 1988-89 with a reduction of the simple average tariff from 51 to 37 per cent, and a reduction in the maximum tariff from 105 to 85 per cent. At the same time, several non-tariff barriers were abolished; these ranged from cumbersome administrative procedures to issue import licences to straightforward import prohibition. The second stage occurred from 1990 to 1994 . At the end of 1994 the 
simple average tariff was 11 per cent. This level of protection is consistent with the Brazilian commitments under the Mercosur Agreement that established a Common External Tariff. During this period the process of elimination of a variety of nontariff barriers was consolidated. As a result of trade liberalisation the volume of trade has more than tripled from 1988, reaching US\$115 billion in 1997.

As an illustration of the impact on the manufacturing sector of the economy of such policy shift, Moreira and Correa (1996) computed the ratios of import and export to production for various sectors. For example, the ratio of imports to production in the electronic and communication equipment sector changed from 11 per cent in 1989 to 78 per cent in 1995 . This ratio changed from 14 per cent to 68 per cent in the capital goods sector during the same period. The export to production ratio in a number of industries such as wood products, non-metallic minerals, paper and steel increased more than two-fold in that period.

\section{Competition policy, anti-trust and regulation}

A 1994 law updated the instruments for implementation of competition policy. CADE, the anti-trust authority, is supposed to act in cases of abuses of market power and anti-competitive practices, including cartels and mergers. The Justice Ministry (SDE), typically based on the economic analysis performed by the Finance Ministry (SAE) initiates the administrative processes. CADE passes judgement, which may involve fining firms for anti-competitive practices, disallowing such practices or undoing a merger or joint venture. As in most modern economies, $\mathrm{CADE}$ is also open to consultation prior to firms pursuing a given merger or practice.

Although the abstract notion of competition policy has been present in Brazil for many years, the economic culture has been one where competition policy in practice meant price controls (Hay, 1998). Mattos (1997) reports that more than 50 per cent of all processes evaluated by CADE in 1996 concerned what is referred to as abusive price increases. These processes were initiated by the Finance Ministry (SAE) because prices of selected goods produced by oligopolised industries (such as pharmaceuticals) had increased considerably more than inflation. Appropriately, CADE has terminated these processes, as its mandate is to promote competition and not become a price control agency.

Mattos has also pointed out another shortcoming of the current implementation of competition policy, namely that CADE's evaluation of market shares in merger cases has focused mainly in the domestic market, ignoring the degree of openness of the economy. Again, this distortion results from an economic culture where imports were not only heavily taxed but also controlled administratively and foreign direct investment was small. Coming to terms with these ideas are just some of the difficulties faced by CADE in its pursuit of competition policy.

The abolition of state monopolies in oil exploration and production, electricity generation and distribution, telecommunications and infrastructure (roads, ports, etc.) has posed additional challenges for competition policy. In fact, many analysts have pointed out that the comprehensive privatisation program undertaken has not 
been accompanied by a coherent strategy about the precise form that regulation and competition policy should take (Hay, 1998; IPEA/DIPPP, 1997).

In particular, there is no clear division of responsibilities between the new regulatory bodies in telecommunications (ANATEL), electricity supply (ANEEL) and oil industry (ANP), the Finance Ministry (SAE), the Justice Ministry (SDE) and CADE itself. Further to complicate things, there are also state regulatory and anti-trust agencies. In addition, the political economy of this process is quite complex as the new regulatory agencies have been partially staffed with former employees of the state monopolies.

To appreciate the coordination problems involved, it is worth citing a current proposal by SAE's Secretary, Mr. Rocha, who proposes a system of agreements between SAE/Ministry of Finance, SDE/Ministry of Justice, CADE and the new regulatory agencies allocating regulative responsibility (Rocha, 1997). Investigation of technical/sector specific issues would be the responsibility of the respective specific agencies (with the help of SAE and SDE for more general economic aspects) with CADE passing judgment. In the more narrow cases, the specific agency would pass judgement and CADE would adjudicate on appeal. Clearly, as new regulatory agencies are established (transport, water, sewerage, etc.), these coordination problems will be amplified.

\section{Privatisation}

As noted above, the Immediate Action Program (PAI) identified government fiscal disorganisation as the cause of the high levels of inflation that persisted until 1994. Therefore, it was recognised that the government should move away from the production of private goods (steel, aeroplanes, chemicals, mineral exploration, ports, transport, electricity, telecommunication, gas, oil, etc) and concentrate its efforts on the provision of basic public health, education and poverty reduction in general. To accomplish this, a large privatisation program was undertaken.

PAI also recognised the importance of privatisation for the elimination of the fiscal deficit. As an example of the burden imposed on the government by the ownership of a large number of firms, US $\$ 21$ billion was allocated from 1982 to 1992 to companies that were later included in the privatisation program (PND). Despite the large onus for the federal government, frequently the government had little say in the administration of these companies due to the complex role played by political interests, both external and internal to the companies.

In summary, the objectives listed under the PAI included the immediate privatisation of the companies in the steel, chemical and fertiliser sectors; the inclusion of the electricity and transport sectors in the privatisation program; and the sale of the government's shares in a large number of privately-controlled companies. More than five years later, the results are quite impressive. Table 6 presents a summary of the privatisation program both at the federal and state levels. At the federal level, the results of the privatisation of the telecommunication sector are listed separately. The total financial result is split into two parts; the revenue from the sale and the transfer of existing debt to the new owners. 
Since the establishment of the PND in 1991, 63 companies (including government ownership of shares of private companies) were sold and the total accumulated revenue at the end of 1998 reached US $\$ 28.8$ billion. The most significant sales were in the steel ( 28 per cent), electricity distribution ( 20 per cent), minerals ( 17 per cent) and chemicals (14 per cent) sectors. In addition, under the PND the operation of ports, railways and federal roads were contracted out. The sale of the large electricity generating companies is scheduled for 1999 and the government expects to obtain in excess of US $\$ 25$ billion.

The federal privatisation program also included the sale of the local and long distance telecommunication companies (US\$12.0 billion) and of the state-operated mobile phone companies (US\$7 billion). In addition, the government auctioned off a second mobile licence for each region. The government fetched an additional US $\$ 7.6$ billion for licences covering almost the entire country.

\section{Table 6: Results of Privatisation Program - 1991/1998 (US\$m)}

\begin{tabular}{|l|c|c|c|}
\hline \multicolumn{1}{|c|}{ Program } & Sales Revenue & Debt Transfer & Total Financial Result \\
\hline $\begin{array}{l}\text { Federal Government } \\
\text { Privatisation }\end{array}$ & & & \\
\hline 1. PND & 19,811 & 9,201 & 28,812 \\
\hline 2. Telecommunications & 26,557 & 2,125 & 28,682 \\
\hline $\begin{array}{l}\text { State Government } \\
\text { Privatisation }\end{array}$ & 22,520 & 5,223 & 27,743 \\
\hline Total & 68,688 & 16,549 & 85,237 \\
\hline
\end{tabular}

Source: Banco Nacional de Desenvolvimento Econômico e Social (BNDES) (www.bndes.gov.br).

The total financial results from the privatisation of companies owned by states (and the sale of the partial ownership of private companies) amounted to US\$27.7 billion. Among the many companies being sold, there were banks, electricity distribution utilities, and even a parking garage in downtown Rio de Janeiro!

\section{Financial Reforms}

Once inflation was under control, the need to reform the financial system became clear. In particular, many years of extremely high inflation induced an increase in the number of financial institutions that use a large number of retailing facilities to profit from the benefits of non-interest-bearing bank accounts. From 1990 to 1994, the fraction of output of financial institutions in the GDP averaged 12 per cent. Once inflation was reduced in 1995, this percentage fell to seven per cent.

The reduction in inflation rates has affected not only the private commercial banks but also state and federal banks. Governors, in the past, have used state banks to finance public spending. In some states the wage bill for public employees 
alone exceeded tax revenue (inclusive of transfers from the federal government). The ability to use state banks to finance large state deficits was perhaps one of the most costly results of the combination of high inflation rates and lack of proper regulatory and supervisory roles of the Central Bank. Mendonça de Barros, Loyola and Bogdanski (1998) report that three and a half years after the introduction of the real, changes occurred, both in the financial regulatory framework and in the organisation of banks. (About one-third of the banks that existed in July 1994 went through some form of ownership change).

Mendonça de Barros and Almeida (1997) identify three stages of reform. The first stage, which lasted from the introduction of the real in July 1994 to mid-1996, involved changes in the ownership of private banks and in the regulatory framework. In this stage, a comprehensive program, known as PROER, was introduced to oversee the process of mergers and takeovers among banks and to provide guarantees for depositors and investors (see below). In the second stage, which started in mid-1996 and is continuing today, the state and federal financial institutions were reorganised (most state banks were either privatised or liquidated) and additional foreign banks were allowed to enter. The final stage is to be characterised by organisational changes in the Brazilian banks. The remainder of this section details some of the regulatory changes in prudential regulation and analyses the results of PROER.

In terms of bank supervision, the changes adopted by the Brazilian government followed the general principles of the Basle Accord. For example, Law no. 9,447 of 15 March 1997 allowed the Central Bank to require that financial institutions with liquidity problems either increase capital, change ownership or merge with other financial institutions. The Central Bank also introduced new rules for the organisation and establishment of new banks. Prudential regulation was also made more stringent than required by the Basle Accord. Minimum capital requirements were increased to ten per cent of assets adjusted by risk. Banks are also required to use adequate risk analysis.

Changes in the structure of the financial sector are still occurring. For example, several foreign banks have been authorised to operate in Brazil since 1996 and other foreign banks gained access to the domestic market by buying shares in existing banks and state banks being privatised.

Of the 271 multiple, commercial, development and investment banks in operation in 1994, 43 have since faced either transference of control, merger or liquidation. As of December 1997, more than $\mathrm{R} \$ 20$ billion have been allocated under the auspices of PROER, mainly to finance the purchase by private institutions of parts of the assets owned by banks under liquidation. ${ }^{1}$

If one includes the R\$8 billion contribution to the increase in capital of a government bank (Banco do Brasil), PROER has involved resources of the order of four per cent of the 1996 GDP. The cost of similar programs, as percentages of GDP, varied from 13 per cent (Argentina, 1982) to 19.6 per cent (Chile, 1985); (Rojas-Suares and Weisbrod, 1995). Caprio and Klingebiel (1996) estimate losses or resolution costs for developed nations, which range from three per cent of GDP for the US saving and loan crisis (1984-1991), to 17 per cent of GDP for the Spanish banking crisis of 1977 to 1985. 
In conclusion, prudential regulation was reformed beyond what was required by the Basle Accord, the supervisory role of the Central Bank has been made more effective by changes in legislation, modern risk analysis has to be used by any bank that wants to operate in Brazil, and PROER has managed to avoid a banking crisis. Of course, any intervention where depositors and investors are reassured that the government will bail banks out sends the wrong incentives: depositors and investors do not have the incentive to investigate a bank's financial situation in detail and banks also do not have the right incentives to manage risk. The legislation that imposes mandatory risk analysis and the improvement in the supervisory ability of the Central Bank will have to counterbalance this lack of incentives.

\section{Conclusion}

After having successfully defended its currency against speculative attacks twice before (after the Mexican crisis of 1995 and after the Asian crisis of 1997), and after an initial success on defending it after the Russian default in 1998, the Brazilian government finally succumbed to pressure and floated its currency in January 1999. The real was trading at R $\$ 1.22 /$ US $\$ 1$ in early January. By the end of February the exchange rate had reached more than R $\$ 2.00 /$ US $\$ 1$, declining to $\mathrm{R} \$ 1.72 / \mathrm{US} \$ 1$ by the end of May.

Unlike East Asia, the Brazilian financial system has undergone some major changes since the Mexican crisis of 1995. Unlike Russia, the Brazilian economy has shown sustained growth in its GDP, exports, industry productivity and agricultural production for the last five years. After more than a decade of high inflation and several failed attempts at stabilising prices based upon artificial price controls and other heterodox experiments, it was finally accepted that the real source of the country's malaise was the disorganisation of the public sector and the resulting fiscal imbalances which were financed by printing money.

With this acceptance came the first concrete opportunity for a lasting reduction in inflation. It brought an opportunity to recover the economy's ability to pursue sustainable economic growth and the government's ability to address social inequalities. The Immediate Action Program of 1993 was the starting point for the introduction of the real in July 1994 and for the institutional changes that followed. These changes and price stabilisation are considerable achievements. The significance of these reforms is highlighted by the fact that, after failing to comply with macroeconomic targets under various IMF agreements during the 1980s, Brazil has on its own managed to successfully implement a unique price stabilisation experiment and several reforms that went beyond the IMF's general repertoire.

Nevertheless, the Asian financial crisis, the Russian default and the speculative attacks on the real that followed these events revealed that there are still many challenges ahead. Chiefly among these is the relationship between the federal and state governments. The latter are yet to reform generous pension funds for state employees that are simply not actuarially feasible. A few, more fiscally minded, governors used part of the resources of the state privatisation programs to set up a 
pension fund for public employees. However, such funds can cover at most a very small fraction (ten per cent) of the existing pensions. States have to follow the footsteps of the federal government and reduce their wage and pension bills and to include, for example, contributions from retirees. Some governments have announced their intentions of pursuing such reforms, while others will not.

A second challenge consists of addressing some of the concerns, raised above, with respect to competition policy. The relationship between the main antitrust authority (CADE) and the new sector-specific regulatory authorities has to be better defined. One possible model is to have the sector-specific agencies dealing with technical issues such as interconnection agreements and access prices, and CADE dealing with more general issues such as pricing behaviour, mergers and acquisitions. There is also an urgent need for the training of officials in the new agencies as some of them may have came from the state monopolies themselves. It is also necessary to counter the perception that, in at least some industries, the privatisation program did not follow from a well-thought through process of introducing competition, but rather as a simple transference of the ownership to the private sector.

The third and perhaps the most difficult challenge ahead consists of resisting the political forces that advocate a return to tariff protection, salary indexation and large fiscal deficits. These pressures may be exacerbated when the exchange rate is flexible and out of the reach of government officials.

\section{References}

Barros, J. R. M. de \& M. F. A. Junior (1997), 'Análise do Ajuste do Sistema Financeiro no Brasil', Ministry of Finance, Brasilia (Working Paper).

Barros, J. R. M. de, G. Loyola \& J. Bogdanski (1998), 'Reestruturação do Setor financeiro', Ministry of Finance, Brasilia (Working Paper).

Bonelli, R (1996), Ensaios sobre Politica Econômica e Industrialização no Brasil, Senai/DPEA, Rio de Janeiro.

Bonelli, R. \& R. Gonçalves (1998), 'Para Onde Vai a Estrutura Industrial Brasileira?', IPEA, Rio de Janeiro (Texto para Discussão no. 541).

Caprio, G. \& D. Klingebiel (1996), 'Bank Insolvencies: Cross-Country Experiences,' World Bank, Washington DC (Working Paper)

Hay, D. (1998), 'Industrial Policy in Brazil: A Framework', IPEA, Rio de Janeiro (Texto para Discussão no. 551).

IPEA/DIPPP (Diretoria de Planejamento e Políticas Públicas) (1997), Boletim de Política Industrial no. 2, Rio de Janeiro, pages 12-14. 
Mattos, C. (1997), 'The Recent Evolution of Competition Policy in Brazil', paper presented to a symposium on Competition policy at the Getulio Vargas Foundation, Rio de Janeiro.

Moreira, M. and P. Correa (1996), 'Abertura Comercial e Indústria: O Que Se Pode Esperar e o Que Se Vem Obtendo', BNDES, Rio de Janeiro (Texto para Discussão no. 40).

Rocha, B. (1997), 'Regulação de Infra-Estrutura e Defesa da Concorrência: Proposta de Articulação', Ministry of Finance, Brasilia (Working Paper).

Rojas-Suares, L. and S. Weisbrod (1995), 'Banking Crises in Latin America: Experience and Issues', International Development Bank, Washington DC.

United Nations Industrial Development Organization (UNIDO) (1997), Industrial Development Global Report - 1996, Vienna.

The author is grateful to John Asker, Steve Dowrick, two anonymous referees and the Editor for many helpful comments. 